\title{
Antiquity
}

Vol. XXIV No. 96

DECEMBER I950

\section{Editorial Notes}

$\mathrm{D}$ ATING the past in years, and not merely in periods, is the aim of archaeology. The C I 4 method just discovered will probably be used to date all sites in future, but its range extends only to about 25,000 B.C., and man existed long before that. Now comes a new technique which promises to carry the story back beyond the limits of $\mathrm{C} \mathrm{I}_{4}$. It is based upon the fact that the deep ocean deposits still forming have been forming continuously over a very long period of time. They are of course stratified, and by making a boring through them and analyzing the contents of the core, certain very important conclusions can be drawn about the climatic changes that took place during and after the Ice Age. These agree quite well with what was already known, and will enable us to give dates in years--i.e. an absolute chronology-to the phases of the Old Stone Age. We hope shortly to publish an article on this subject. Meanwhile we quote (with the permission of the Editor and Author) from an article which appeared in The Times, 22 Sept. 1950, p. 5. It is by Dr J. D. H. Wiseman, of the British Museum (Natural History). 'As the distance from the top of the core of the sample corresponding with the climatic optimum is known, it is possible to calculate with a considerable degree of accuracy the age of any portion of the cores, provided the distribution of calcium carbonate as well as the original water content is known. It is in this way possible to assign dates to climatic oscillations. About I I7,000 B.C. there was a distinct but sharp minimum temperature. Thereafter the temperature rapidly rose, and with some minor oscillations reached a maximum at 78,000 B.C. The temperature then fell to a minimum at 68,000 B.C. which was not as cold as the minimum at I 17,000 B.C. After that the temperature increased until 43,000 B.C. ; it then remained essentially constant for 16,000 years. There was a distinct fall in temperature and at 23,000 B.C. there was a minimum which was not as cold as the two preceding minima. The temperature then increased, remained for some time essentially constant, and at 10,000 B.C. there was an indistinct minimum. After that the temperature rose rapidly until 7,000 B.C., when there was a more gradual rise until the climatic optimum at 3,000 B.c. was reached. These dates are approximate, as further investigations might lead to minor modifications'.

\section{$*$}

Every year the British Association for the Advancement of Science publishes a brochure containing the presidential addresses delivered to its thirteen sections. They provide an admirable conspectus of the general state of knowledge in the field of science, and though unfortunately there are always some presidents who lack the powers of lucid expression, they make good reading on the whole. The address delivered to Section $\mathrm{L}$ 


\section{ANTIQUITY}

(Education) by Mr W. F. Oakeshott, headmaster of Winchester College, is short but stimulating. If we have understood him correctly, he laments the cleavage which began (as he thinks) soon after the middle of the $19^{\text {th }}$ century, when a general acquaintance with the state of scientific knowledge gradually ceased to be part of the normal educated person's mental equipment. 'The educated man of the 18 th century still regarded the discoveries of the scientist as being part of his normal reading '; and Darwin's Origin of Species and Lyell's Principles of Geology were ' widely read by men who were not primarily scientists'. The reason alleged for this cleavage is that the specialist no longer feels an obligation to write books for the layman because that service is now performed by others. Archaeology is cited as an example. 'What is wanted is that the expert archaeologist... should write books for the general public'. We rubbed our eyes in amazement when we came to this sentence. Has $\mathrm{Mr}$ Oakeshott, who calls himself an 'interested amateur' of archaeology, never heard of the many books written during the last two or three decades by 'expert archaeologists', some of them by a distinguished Wykehamist ? Is there any 'expert archaeologist' in this country, indeed, who has not written at least one such book? Has he never heard of the Penguins and Pelicans, and that some of them are prescribed as standard advanced text-books in American universities? Has he never heard of ANTIQUiTY ? Nor does his accusation hold against specialists in other branches of science; there have been many such books published. The fault lies not with the experts but with educators who fail to use their books or even, as it seems, to know that such exist.

What is the result? The higher posts in the Civil Service are filled with people who are ignorant of the most vital knowledge of our age, and consequently out of sympathy with that spirit of research which animates and is the driving force of many lives. We may be too optimistic, but we cannot believe that bureaucrats are all as bad as $\mathrm{Mr}$ Oakeshott's former chief who (he says) enjoyed 'the power [his post] gave him of doing harm to better men than he was'. We have all met people of this kind, but we cling desperately to the theory that ignorance rather than mere love of power is responsible. In fact, like Mr Oakeshott, we prefer St. Benedict's view of human nature to that of Machiavelli. Ignorance not malice is surely responsible for most of the misunderstandings that arise between the world of learning and science on the one hand and that of politicians and administrators on the other. For that ignorance our educational system must bear part of the blame; but the remedy is not easily found, for that system is controlled in the last resort by its own products-or victims. 